\title{
Detection of Sulphide Deposit Using Uranium/Potassium Ratio
}

\section{Map}

\author{
Ohi Jerry Ohioma
}

\begin{abstract}
Potassium $(K)$ response is associated with minerals that can be easily weathered, whereas uranium $(U)$ is usually related to residual clay, oxides and accessory minerals. With a view to interpret for the detection of sulphide deposit based on similar responses exhibited by the various rock units, radiometric data set was interpreted. The study area is located within Latitude +8000 '00' 'to +8030'00'" and Longitude +5030'00''E to +6000'00' 'E. The data was collected in most parts of the Nigeria by Fugro Airborne Services Ltd. Johannesburg in collaboration with the Nigerian Geological Survey agency using a light aircraft that was flown in NW-SE direction with a nominal terrain clearance of $80 \mathrm{~m}$ and at a speed of $70-80 \mathrm{~m} / \mathrm{s}$, with a flight line spacing of 500 $m$ apart. The acquired data was subjected to elemental concentration enhancement using Geosoft Oasis Montaj Software. From the interpreted data, the red coloured portions indicate high uranium and low potassium formations $(H-U / K)$, while the blue coloured portions indicate low uranium and high potassium formations $(L-U / K)$. The regions $L-U / K$ have recorded low $U / K$ ratios, meaning that $L-U / K$ have very low uranium count rates as compared to the count rates of potassium in these regions; this signifies potassium abundance. This also suggests igneous activities that usually culminate to the emplacement of the meta-volcanic lithologies. $\mathrm{H}-\mathrm{U} / \mathrm{K}$ and $M-U / K$ (Moderate U/K formations) are seen to have patches of high U/K ratios within the central portions. This high $U / K$ ratio was therefore, as a result of sulphide deposition.
\end{abstract}

Keywords: Uranium/Potassium Ratio, Sulphide Deposit, Radiometric Data, Ratio Map

Department of Physics, University of Benin, Benin City, Edo state, Nigeria ohioma.jerry.ohi@gmail.com

Ghana Journal of Geography Vol. 12(1), 2020 pages 145- 158

https://doi.org/10.4314/gig.v12i1.8 


\section{Introduction}

Deposition of sulphides can be caused by boiling, by a drop-in temperature, by mixing with a cooler solution or by chemical reactions between the solution and a reactive rock. Although hydrothermal minerals may form in any rock, deposition is preferentially influenced or localized by certain kinds of rock. For example, lead-zinc-silver ores in some parts of Mexico occur in dolomitic rather than pure limestone; the reverse is true at Santa Eulalia, where massive sulfide deposits end abruptly at the limestone-dolomite contact. Measurements of variations in the mineral composition (Wilford et al., 1997), properties of soils and their parent geological material in order to map lateral lithological changes can be done by airborne radiometric survey. It involves the measurement of naturally occurring uranium $(\mathrm{U})$, thorium $(\mathrm{Th})$ and potassium $(\mathrm{K})$, which could be found as trace elements that exist in rock forming minerals and soil profiles. In radiometric survey, the gamma ray response from the radioelements $(\mathrm{K}, \mathrm{U}$ and $\mathrm{Th})$ in the rocks can be related to the distribution of the various lithologies. Large areas of the world have been covered by ground and airborne gamma ray surveys and many national and regional radiometric maps have been compiled and published by the International Atomic Energy Agency, etc (IAEA, 1995; IAEA, 1997; Green et al., 1993). 
Nigeria is divided into three major litho-petrological components. We shall be concentrating on the basement complex of Nigeria for this study. Within the basement complex of Nigeria, four major petro-lithological units are distinguishable, namely:

A. Migmatite-Gneiss Complex (MGC)

Migmatites, Gneisses, Granite-Gneisses

B. Schist Belts (Meta-sedimentary and Meta-volcanic rocks)

Phylites, Schists, Pelites, Quartzites, Marbles, Amphibolites

C. Older Granites (Pan African Granitoids)

Granites, Granodiorites, Syenites, Monzonites, Gabbro, Charnockites

D. Undeformed Acid and Basic Dykes

Muscovite-, tourmaline- and beryl-bearing pegmatites, applites and syenite dykes; basaltic, doleritic and lampropyric dykes

\section{The Migmatite-Gneiss Complex (MGC)}

The Migmatite-Gneiss Complex is generally considered as the basement complex sensustricto (Rahaman, 1988; Dada, 2006) and it is the most widespread of the component units in the Nigerian basement. It has a heterogeneous assemblage comprising migmatites, orthogneises, paragneisses and a series of basic and ultrabasic metamorphosed rocks. Petrographic evidence indicates that, the Pan-African reworking led to recrystallisation of many of the constituent minerals of the Migmatite - Gneiss Complex by partial melting with majority of the rock types displaying medium to upper amphibolite facies metamorphism. The Migmatite-Gneiss Complex has ages ranging from Pan-African to Eburnean.

The Migmatitie-Gneiss Complex also termed by some workers as the "migmatite-gneiss-quartzite complex" makes up about $60 \%$ of the surface area of the Nigerian basement (Rahaman and Ocan, 
1978). These rocks record three major geological events (Rahaman and Lancelot, 1984); the earliest, at 2,500 Ma, involved initiation of crust forming proceses (e.g. the banded Ibadan grey gneiss of mantle origin) and of crustal growth by sedimentation and orogeny; next came the Eburnean, 2,000 $\pm 200 \mathrm{Ma}$, marked by the Ibadan type granite gneisses; this was followed by ages in the range from 900 to $450 \mathrm{Ma}$ which represent the imprint of the Pan-African event which not only structurally overprinted and re-set many geochronological clocks in the older rocks, but also gave rise to granite gneisses, migmatites and other similar lithological units. The close analogy in time with the development of the Birrimian of the West African Craton is striking. However, although gold, manganese and iron mineral deposits are associated with Birrimian rocks, the same age rocks in Nigeria are very sparsely, if at all, mineralized. The extent of Eburnean and older rocks in Nigeria is not known. Definite geochemical evidence for the existence of these rocks exists for the area south of latitude 9॰N (Rahaman and Lancelot, 1984). Lithologically, similar rocks in other parts of Nigeria, especially in the northeast and southeast, have given only PanAfrican ages (Tubosun, 1983).

Many areas in Northern, Western and Eastern Nigeria are covered by rocks of the MigmatiteGneiss Complex. These areas include, but not limited to: Abuja, Keffi, Akwanga, Bauchi, Kaduna, Kano, Funtua, Okenne, Egbe, Isanlu, Mopa, Ajaokuta (in northern Nigeria); Ibadan, Ile-Ife, Akure, Ikerre, (in Western Nigeria) and Obudu and the Oban Massif areas in Eastern Nigeria.

The migmatite-gneisse complex is composed of a series of rock types including migmatites, gneisses of various origins and a series of metamorphosed basic and ultrabasic rocks represented by amphibolites and talc Schist. Definite meta-sedimentary rocks are represented by quartzites, marble and mica Schists (Wilson, 1922; Russ, 1957; Hockey and Jones, 1964). The metasedimentary rocks have been referred to as "older Meta-sediments" by Oyawoye (1964) and McCurry (1976). The rocks have been metamorphosed in the middle to upper amphibolite facies. Russ (1957) considered that the oldest member of the gneissic complex represents the oldest member of the Precambrian rocks of the Northwestern Nigeria and that it evolved by successive sedimentation, deformations, metamorphism and igneous intrusions over a vast period in the history of the basement. 


\section{The Schist Belt (Meta-sedimentary and Meta-volcanic Rocks)}

The Schist Belts comprise of low grade, meta-sediment-dominated belts trending $\mathrm{N}-\mathrm{S}$ which are best developed in the western half of Nigeria. These belts are considered to be Upper Proterozoic supracrustal rocks which have been infolded into the migmatite-gneiss-quartzite complex. The geochronology of the Schist belts remains problematical; although, the ages of the intrusive crosscutting Older Granites provide a lower limit of $750 \mathrm{Ma}$. An age of 1,040 $\pm 25 \mathrm{Ma}$ for the Maru Belt phyllites has been accepted as a metamorphic age by Ogezi (1977). The Schist belt rocks are generally considered to be Upper Proterozoic. The geochemistry of the amphibolite complexes within the Schist belts has also led to controversy.

The belts are confined to a NNE-trending zone of about $300 \mathrm{~km}$ wide. The area to the west of this zone is made up of gneisses and migmatites (Burke and Dewey, 1972). Similarly to the East, no Schist belts are known for a distance of $700 \mathrm{~km}$ until in Cameroun where a number of Schist belts, considered to be Upper Proterozoic, occur in the Pan-African granite-migmatite terrain north of the Congo Craton.

The relationship between the Schist belts of the north-western and southwestern Nigeria is not clear, partly because they are separated by Cretaceous and tertiary sediments of the Niger Basin.

\section{The Older Granites (Pan African Granitoids)}

The term "Older Granite" was introduced by Falconer (1911) to distinguish the deep-seated, often concordant or semi-concordant granites of the Basement Complex from the high-level, highly discordant tin-bearing granites of Northern Nigeria. The Older Granites are believed to be pre and post-tectonic rocks which cut both the migmatite-gneiss-quartzite complex and the Schist belts. They range widely in age (750-450 Ma) and composition. They represent a varied and long lasting (750-450 Ma) magmatic cycle associated with the Pan-African orogeny. The rocks of this suite range in composition from tonalites and diorites through granodiorites to true granites and syenites. Charnockites form an important rock group emplaced during this period. They are generally high level intrusions and anataxis has played an important role (Rahaman, 1981). The Older Granites 
suite is notable for its general lack of associated mineralisation although the thermal effects may play a role in the remobilisation of mineralizing fluids.

The Older Granites are the most obvious manifestation of the Pan-African orogeny and represent significant additions of materials (up to $70 \%$ in some places) to the crust (Rahaman, 1988). Attempt to classify the Older Granites with respect to timing during an orogenic event are valid over only short distances. Contact features between members of the Older Granites suite suggest the coexistence of several magmas. Compositionally, the granites plot in the field of calc-alkaline rocks on the AFM diagram and although they contain significant amount of alkalis, are also often slightly corundum normative. Dada (2006) was of the opinion that the term "Pan African Granitoids" be used for the Older Granites not only on the merit of age which was not available at the time they were named Older Granites, but because it covers several important petrologic groups formed at the same time.

The granitoids which outcrop with the Schist belts in Northwestern and Southwestern Nigeria include biotite granites, biotite muscovite granites, syenites, chanockites, serpentinites and anorthosites.

Rahaman (1988) discarded the earlier classification of members of the Older Granites suite on the basis of their texture, mineraological composition and the relative timing of their emplacement. In its place, members of the Older Granite suite were classified as follows, based mainly on the textural characteristics:

1. Migmatitic granite

2. Granite gneiss

3. Early pegmatites and fine-grained granite

4. Homogeneous to coarse porphyritic granite

5. Slightly deformed pegmatite aplites and vein quarz and

6. Undeformed pegmatites, two-mica granites and vein quartz 
In Northern Nigeria, the abundance of Pan-African granites appears to increase eastward. In the west of Zaria these occur as isolated intrusions (McCurry, 1972), whereas in the region between Rahama and the Mesozoic-Cenozoic cover the intrusive granites and related rocks envelope remnants of Migmatites. McCurry (1972) working mainly west of Zaria divided the granites into two main groups according to their field relationships. The first "syntectonic" group comprised elongate batholithic sheets that are partly concordant and foliated. The second group "late tectonic" are made up of poorly foliated discordant bodies, rich in mafic xenoliths and having a lower proportion of potash feldspar. The late granites are considered to be the products of widespread mobilisation and reactivation of older basement rocks during the Pan-African orogeny. The Older Granites occur intricately associated with the Migmatite-Gneiss Complex and the Schist Belts into which they generally intruded. Older Granite rocks, therefore, occur in most places where rocks of the Migmatite-Gneiss Complex or of the Schist Belt occur. However, Older Granites are particularly noteworthy in and around Wusasa (Zaria), Abuja, Bauchi, Akwanga, Ado-Ekiti and Obudu areas. In Bauchi area and some parts of Southwestern Nigeria, most of the Older Granite rocks occur as dark, greenish-grey granites with significant quantities of olivine (fayalite) and pyroxene occurring with quartz, feldspars and micas. For this unusual composition, the Older Granites in these areas are termed Bauchite (in Bauchi area) and Oyawoyite (after Professor Oyawoye who first mapped them) in southwestern Nigeria. For uniformity of terminology, both the Bauchites and Oyawoyites constitute the charnockitic rocks (Charnockites) of the Basement Complex.

According to Dada et al. (1989), it was at Toro that charnockite was first described within the Nigerian basement by Falconer (1911) where it was then referred to as a "quartz diorite porphyrite." It was assumed to present a certain affinity with the basic members of the charnockitic series of the Ivory Coast. Wright and McCurry (1970) described it as an annular complex of hypersthene diorite at the centre of three circular, concentric granites. He considered the hypersthene diorite as older than the granites from contact relations. Cooray (1975) in his review of charnockitic rocks of Nigeria came to the same conclusion, using for argument the presence of granitic veins in the diorite, of dioritic xenoliths in granites and microcline porphyroblasts in the diorite. A fieldstudy of the same hybrid rocks led Rahaman (1981) to consider both the granites and the charnockites as either contemporaneous or the latter emplaced shortly after the former. 
The basement in Toro area consists of gneisses and migmatites into which the Toro Charnockitic Complex intruded (Dada et al., 1989); Older Granites and charnockites which constitute the complex proper; and undeformed basic (doleritic) dykes considered to be later than the PanAfrican Granites.

The Toro charnockite was described by Dada et al. (1989) to be typically greenish black, fine to medium-grained, equigranular and massive, sometimes porphyritic.

The granites consist of the periphery of the complex (in contact with the migmatitic gneiss) towards the centre (in contact with the hypersthene diorite) of a fine to medium grained biotitemuscovite granite, an equigranularbiotitehornblende granite and a porphyritic biotite-hornblende granite. In general, these granites as well as the diorites are not affected by a penetrative deformation, but undulatory extinction of the quartz and fractures in feldspar crystals indicate local brittle deformation.

The Older Granites are recognized as of Pan-African age. Despite the close association and field relations with the Older Granites, older ages have been suggested for the charnockites. These ages are in contradiction to the evidence of mix reactions at the contact between the charnockites and the Older Granites advanced by Rahaman (1981). Van Breemen et al. (1997) obtained the imprecise ages of $663 \pm 164 \mathrm{Ma}$ and $668 \pm 128 \mathrm{Ma}$. on the bauchites in the areas around Bauchi. Tubosun et al. (1984) using U-Pb method on zircons attributed precise Pan-African ages of $620 \pm$ $20 \mathrm{Ma}$ and $634 \pm 21 \mathrm{Ma}$ to the charnockites of Ikerre and Akure respectively. For the Idanre Complex they obtained late Pan-African ages of $580 \pm 10$ Ma and $593 \pm 11$ Ma thereby confirming definite Pan-African ages for the charnockitic complexes of SW Nigeria. Charnockitic rocks constitute one of the important petrological units within the Precambrian Basement Complex of Nigeria. They are generally characterized by their dark greenish to greenish grey appearance which makes them easily recognizable in hand specimen. They usally contain quartz + plagioclase + alkali feldspar +orthopyroxene + clinopyroxene + hornblende \pm biotite \pm fayalite. Accessory minerals are usally zircon, apatite and iron ores (Olarewaju, 2006). Apart from Toro, other localities of charnockite occurrence include Bauchi, Ado-Ekiti, Ikere (Ekiti), Akure, Idanre and in the Obudu Plateau. 


\section{Undeformed Acid and Basic Dykes}

The undeformed acid and basic dykes are late to post-tectonic Pan African. They cross-cut the Migmatite-Gneiss Complex, the Schist Belts and the Older Granites. There are 2 major portions that form the undeformed acid and basic dykes, they are:

a) Felsic dykes that are associated with Pan African granitoids on the terrain such as the muscovite, tourmaline and beryl bearing pegmatites, microgranites, aplites and syenite dykes (Dada, 2006)

b) Basic dykes that are generally regarded as the youngest units in the Nigerian basement such as dolerite and the less common basaltic, felsite and lamprophyric dykes.

The age of the felsite dykes has been put at between 580 and $535 \mathrm{Ma}$ from $\mathrm{Rb}-\mathrm{Sr}$ studies on whole rocks (Matheis and Caen-Vachette, 1983; Dada, 2006), while the basic dykes have a much lower suggested age of $500 \mathrm{Ma}$ (Grant, 1970). The structural and geochronological importance of this suite of rocks, which have been put to immense chronological use elsewhere are often overlooked in Nigeria. When they cross-cut basement, they could be used to infer relative age of metamorphic structures and rock suites and could also suggest the existence of older basement windows in the Nigerian Schist belts, apart from the immense guide they provide in sampling for isotope geochemistry, analysis and interpretation (Dada, 2006).

\section{Study site}

The study area is located within 8000 '00' $\mathrm{N}$ to 8030 '00' $\mathrm{N}$ and 5030 '00' $\mathrm{E}$ to 6000'00' $\mathrm{E}$. The geology of Nigeria, as detailed in Kogbe (1989), is made up of three main rock groups: Precambrian Basement Complex, Younger Granites and Sedimentary Basins. The study area is a part of the Schist belt of the Precambrian Basement Complex of North Central Nigeria. The Basement Complex forms part of the Pan-African mobile belt which lies between the West-African and Northwest of Congo Craton and south of the Tuareg Shield about 600 Ma ago (Black 1980, Ajibade et al., 1987). The Pan African deformation was accompanied by a regional metamorphism, migmatization and extensive granitization and gneissification which produced syntectonic granites 
and homogeneous gneisses (Abaa, 1983). Late tectonic emplacement of granites and granodiorites and associated contact metamorphism accompanied the end stages of this last deformation. The end of the orogeny was marked by faulting and fracturing (Gandu et al., 1986; Olayinka, 1992).

\section{Methodology}

The data was collected in most parts of the Nigeria by Fugro Airborne Services Ltd. Johannesburg in collaboration with the Nigerian Geological Survey agency using a light aircraft that was flown in NW-SE direction with a nominal terrain clearance of $80 \mathrm{~m}$ and at a speed of $70-80 \mathrm{~m} / \mathrm{s}$, with a flight line spacing of $500 \mathrm{~m}$ apart. The major software used to process and enhance the data is the Geosoft (Oasis Montaj). Golden Software Surfer 10 was also used to accentuate relevant portions of the map. A very mobile element in most geological processes is Uranium; an enrichment of uranium may or may not be accompanied with an enrichment of potassium. The $\mathrm{U} / \mathrm{K}$ ratio is therefore not a good indicator in identifying mineralisation. Notwithstanding, U/K ratios are indicative of sulphide deposits and typically, gold bearing quartz veins carry some sulphides. Mineralized wall rocks are common adjacent to known veins and may be impregnated with fine grained sulphide minerals (Airo, 2007). Other works in this area were also consulted for better understanding of the geology of the area (Ohioma et al., 2017, Ohioma et al., 2017, Ohioma et al., 2019).

\section{Results and Discussion}

Geosoft (Oasis Montaj) was used to tag different colours with different elements. Red indicated Uranium and blue indicated Potassium. A number of the $\mathrm{U}$ intensities are associated with zones of mineralisation. Low $\mathrm{Th} / \mathrm{K}$ and low $\mathrm{U} / \mathrm{K}$ over potassic formations within the concession are likely to be characterized with slightly weathered and highly leached soils respectively (Appiah, 2015). From the Uranium/Potassium (U/K) ratio map in Figure 1, the deep red coloured portions indicate high uranium and low potassium formations $(\mathrm{H}-\mathrm{U} / \mathrm{K})$, while the deep blue coloured portions indicate low uranium and high potassium formations (L-U/K). The regions L-U/K have recorded low $\mathrm{U} / \mathrm{K}$ ratios meaning that $\mathrm{L}-\mathrm{U} / \mathrm{K}$ have very low uranium count rates as compared to the count 
rates of potassium in these regions; this is an indication of potassium enrichment. This also suggests igneous activities that usually culminate in the emplacement of the meta-volcanic lithologies. Airo (2007) stated that high U/K ratios signifies sulphide deposition. H-U/K and M$\mathrm{U} / \mathrm{K}$ (Moderate $\mathrm{U} / \mathrm{K}$ formations) are seen to have patches of high $\mathrm{U} / \mathrm{K}$ ratios within the central portions; this high $\mathrm{U} / \mathrm{K}$ ratio is, therefore, as a result of sulphide deposition.

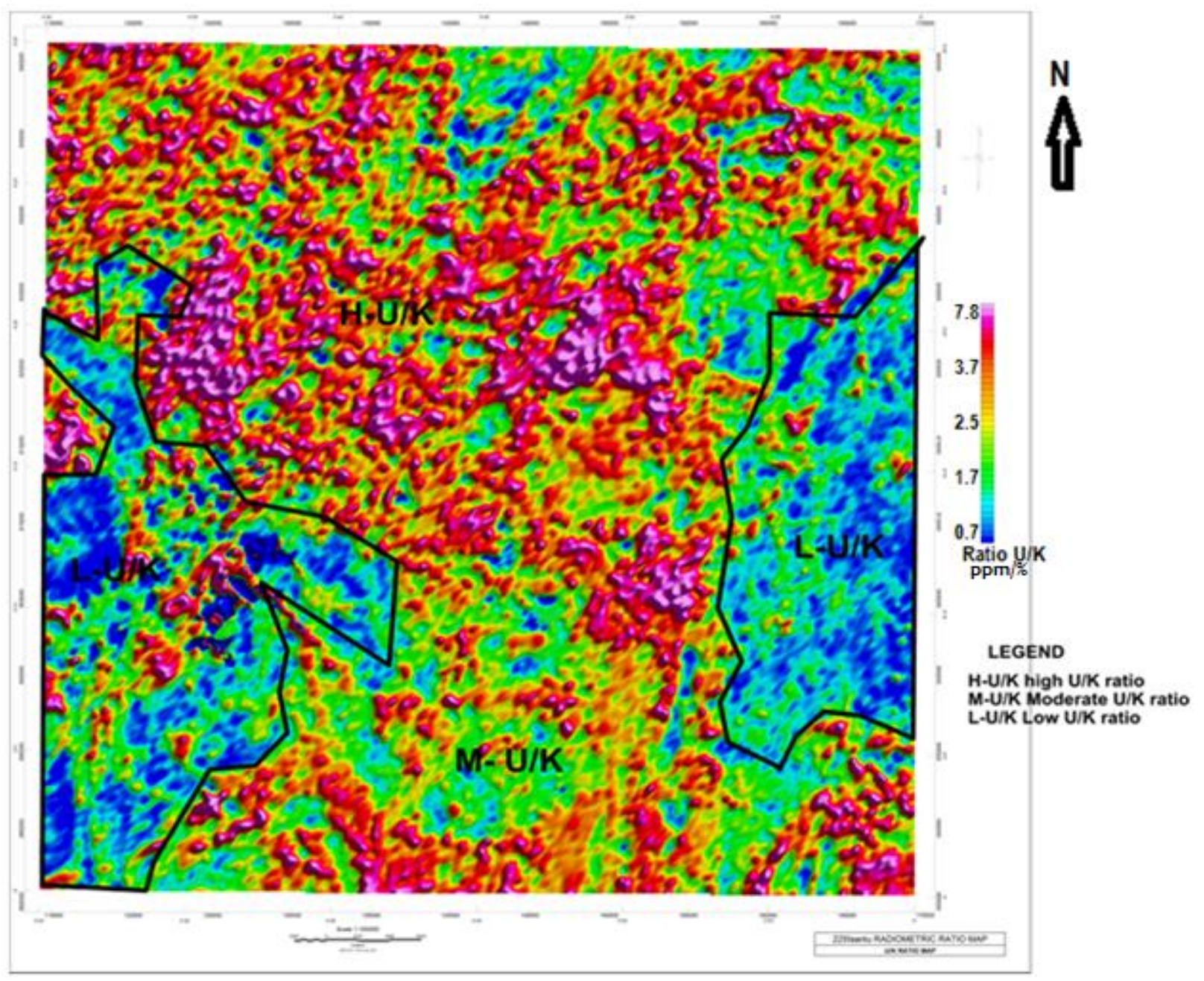

Figure 1: Radiometric uranium/potassium ratio map of Isanlu sheet 225. 


\section{Conclusion}

It is shown that $\mathrm{H}-\mathrm{U} / \mathrm{K}$ have high $\mathrm{U} / \mathrm{K}$ ratios meaning high Uranium having an associated low Potassium, this observation is suggestive of suphide deposit, because sulphide deposits are characterized by an increase in $\mathrm{U}$ and a decrease in $\mathrm{K}$; which lead to enhanced ratio values of $\mathrm{U} / \mathrm{K}$. So, the central region of the map can be said to contain high sulphide deposits. The Low $U / K$ regions indicate highly leached soils because of the low Uranium having an associated high Potassium concentration.

\section{Acknowledgement}

The authors appreciate the help from Nigerian Geological Survey Agency for making the data available for this study.

\section{References}

Abaa, S. I. (1983). The Structure and Petrography of alkaline rocks of the Mada Younger Granite Complex, Nigeria. Journal of African Earth Science 3:107-113.

Airo, M. L. (2007). Application of Aerogeophysical Data for Gold Exploration: implications for the Central Lapland greenstone belt. Geological Survey of Finland, Special Paper 44, pp.189.

Ajibade, A. C., Woakes, M. and Rahaman, M. A. (1987). Proterozoic crustal development in the Pan-African regime of Nigeria. American Geophysical Journal, pp.259 -271.

Appiah, D. (2015) Aero-magnetic and Airborne Radiometric Data Interpretation on Chirano Area of the Sefwi Gold Belt, Pp 82.

Black, R. D. (1980). Upper Cretaceous and Tertiary geology of Mangatu state Forest, Raukumara Peninsula, New Zealand. New Zealand journal of geology and geophysics 23:293-312.

Burke, K. C., Dewey, J. F. (1972). Orogeny in Africa. In: Dessauvagie, T.F.J., Whiteman, A.J. (Eds.), African Geology. Department of Geology, University of Ibadan, Ibadan, pp. 583-608.

Cooray, P. G. (1975). The charnockitic rocks of Nigeria. Pitchamutu Volume, Banglore University, India, pp 50-73. 
Dada, S. S., Lancelot, J. R. and Briqueu, L. (1989). Age and origin of the annular charnockitic complex at Toro, Northern Nigeria: U-Pb and Rb-Sr evidence. J. Afr. Earth Sci., 9:227-234.

Dada, S. S. (2006). Proterozoic evolution of Nigeria. In: Oshi O (Ed) The basement complex of Nigeria and its mineral resources (A Tribute to Prof. M. A. O. Rahaman). Akin Jinad and Co. Ibadan, pp.29-44.

Falconer, J. D. (1911). The geology and geography of Northern Nigeria. Macmillan, London, pp. 135

Gandu, A. H., Ojo, S. B. and Ajakaye., D. E. (1986). A gravity study of the Precambrian in the Malufashi area of Kaduna State, Nigeria. Tectonophysics 126:181-194.

Grant, N. K. (1970). Geochemistry of Precambrian basement rocks from Ibadan, southwestern Nigeria, Earth and Planetary. Science Letters, pp.10, 29-38

Green, B.M.R., Hughes, J. S. and Lomas, P. R. (1993). Radiation Atlas. Natural Sources of Ionizing Radiation in Europe, CEC, Luxemburg. pp. 83.

Hockey, R. O. and Jones, M. A. (1964). The Geology of Part of South Western Nigeria. Nigeria Geological Survey Bulletin, No 31 pp. 1-101

International Atomic Energy Agency (1995). Application of Uranium Exploration Data and Techniques in Environmental Studies. IAEA-TECDOC-827, Vienna.

International Atomic Energy Agency (1997). Uranium Exploration Data and Techniques Applied to the Preparation of Radioelement Maps. IAEA-TECDOC-980, Vienna.

Kogbe, C. A. (1989). Review of the basement geology of southwestern Nigeria. In: Geology of Nigeria.Elizabethan publishing Company Lagos, pp. 41-58 (originally written by Rahman, M. A., 1976).

Matheis, G and Caen-Vachette, M. (1983). Rb-Sr isotopic study of rare-metal bearing and barren pegmatites in the Pan-African reactivation zone of Nigeria. J. Afr. Ear. Sci. 1: pp.35-40.

McCurry, F. (1972). Geology of Degree Sheet 21, Zaira, Nigeria Overseas Geology and Mineral Resources, pp.45

McCurry, P. (1976). Geochemistry of calc-alkaline volcanics in Northwestern Nigeria and a possible Pan-African suture zone. Earth and Planetary Science Letters, pp.37, 90-96

Ogezi, A. E. (1977). Geochemistry And Geochronology of Basement Rocks of N. W. Nigeria Unpublished Ph.D. Thesis, University of Leeds. Pp.39-111

Ohioma, J. O., Adegbite, J. T., Ehilenboadiaye, J. I. (2017). Geophysical Identification of Hydrothermally Altered Structures That Favour Gold Mineralisation. J. Appl. Sci. Environ.Manage.Vol.21(6)1047-1050. doi: https://dx.doi.org/10.4314/jasem.v21i6.8

Ohioma O. J., Ehilenboadiaye J. I., Aiyanbuede D. I. (2019). Upward Continuation Portrayal of Features in the Schist Belt of Nigeria Using Geosoft Oasis Montaj. Journal of Research in Forestry, Wildlife \& Environment Vol. 11(2) June, 2019 pp. 69-73 
Ohioma, O., Ezomo, F. and Akinsunmade, A. (2017). Delineation of Hydrothermally Altered Zones that Favour Gold Mineralization in Isanlu Area, Nigeria Using Aeroradiometric Data. International Annals of Science, 2(1), 20-27.doi: https://doi.org/10.21467/ias.2.1.20-27

Olarewaju, V.O. (2006). The Charnockitic Intrusive of Nigeria. In: The Basement Complex of Nigeria and its Mineral Resources, Oshin, O. (Ed.). Akin Jinad Co., Ibadan, Nigeria, pp: 4570.

Olayinka, A. I. (1992). Geophysical siting of boreholes in crystalline basement areas of Africa. J. Afr. Earth Sci. 14:197-207.

Oyawoye, M. O. (1964). The geology of the basement complex. Journal of Nigeria Mining, Geology and Metallurgy. Volume 1, pp. 87-102.

Rahaman, M. A. (1981). Recent Advances in the study of the Basement complex of Nigeria. In the Precambrian Geology of Nigeria: Proceedings of symposium organized by Geological survey of Nigeria. Pp. 37-85

Rahaman, M. A. (1988). Recent advances in the study of the basement complex of Nigeria. In: Geological Survey of Nigeria (Ed) Precambrian Geol Nigeria, pp. 11-43.

Rahaman, M. A. and Lancelot, J. R. (1984). Continental crust evolution in SW Nigeria: Constraints from U/Pb dating of pre-Pan-African gneisses. In: Rapport dáctivité 1980-1984. Document Travaux Centre Geologie et Geophysique, Montpellier, II pp.4 41.

Rahaman, M.A. and Ocan, O. (1978). On relationships in the Precambrian Migmatite-gneisses of Nigeria. Niger J Min Geol 15: 23-32.

Russ, W. (1957). The geology of parts of Niger, Zaria and Sokoto Provinces. Geological Survey of Nigeria Bulletine 27:1-42.

Tubosun, I. A., (1983). Geochronologie U/Pb du socleprecambrien du Nigeria. Doctorate Thesis (3 degree Cycle). Universite des Sciences et Techniques du Languedoc, Montpellier. France. Pp.93

Tubosun, I. A., Lancelot, J. R., Rahaman, M. A. and Ocan, O. (1984). U-Pb Panafrican ages of two charnockite-granite association from southwestern Nigerian. Contributions to Mineralogy and Petrology 88: 188-195.

Van Breemen, O., Pidgeon, R. and Bowden, P. (1997). Age and isotopic studies of Pan-African granites from north-central Nigeria. Prec. Res. 4: 307-319.

Wilford, J. R., Bierwirth, P. N. and Craig, M. A. (1997). Application of airborne gamma-ray spectrometry in soil/regolith mapping and applied geomorphology. AGSO Journal of Australian Geology and Geophysics, 17(2):201-216.

Wilson, R. C., (1922). The geology of the fVesternRailzuay. Section 1. Iddo to Okuku (with notes by A. D. N. Bain and fV. Russ). Geol. Sur. Nigeria, Bull. 2, 63 pp., 9

Wright, J. B. and McCurry, P. (1970). Geology: The Geological Map of the Zaria Area. In: Zaria and its Region, Mortimore, M.J. (Ed.). Ahmadu Bello University, Department of Geography, Zaria, pp: 5-12. 